\title{
PENGARUH PENYULUHAN TERHADAP PERUBAHAN PENGETAHUAN BAGI IBU-IBU PKK KELURAHAN PENGGARON LOR TENTANG PEMANFAATAN TANAMAN PISANG SEBAGAI MEDIA MENJAGA KESEHATAN GIGI DAN MULUT
}

\author{
Yayun Siti Rochmah*, Minidian Fasitasari ${ }^{* *}$
}

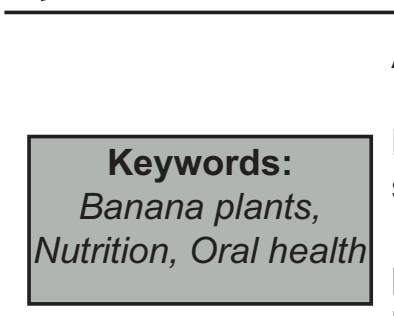

\section{ABSTRACT}

Background: Banana counted as nearly perfect food since it contains six nutrients : water, sugar, proteins, fats, vitamins, and minerals . Because of that, bananas are often used as a staple food for most people because of its nutritional value. However, sometimes people do not realize the benefits of bananas as a whole, from leaves, fruits, flowers and stems of the bananas. Penggaron Lor society, still minimal in using the banana plant. Usually the community will sell fruit and leaves to the market, so that the results obtained from the banana plant community less than optimal. Method : This study is an observational analytic study. The research was done in the Village of Penggaron Lor Semarang, and was conducted in March-June 2014. The instrument in this research was primary data obtained directly from respondents through interviews using questionnaires distributed before and after counseling . To determine whether there are differences in knowledge before and after counseling on the benefits of banana plants as a medium for maintaining oral hygiene, statistical test Wilcoxon Sign Ranks test was conducted, and processed with SPSS. Result: The results of SPSS calculation because the data is not normal ( $p$ value $<0.05$ ), then the data was processed using the non-parametric test for two sample pairs, ie Wilcoxon Sign Ranks test, and obtained $p$ value of 0.008 . This means that there was a significant difference between the mean value of the pre-test and post-test. Conclusion : there are differences in knowledge before and after counseling, counseling means that a significant impact on respondents' knowledge of the benefits of banana plants for maintain oral health

\section{PENDAHULUAN}

Di Indonesia angka kejadian karies gigi masih tergolong tinggi. Berdasarkan data Risdesdas 2013 proporsi penduduk Jawa Tengah yang bermasalah dengan gigi adalah sebesar $25,8 \%$. Hal ini disebabkan oleh banyak faktor diantaranya masih rendahnya tingkat pengetahuan masyarakat tentang cara menjaga kesehatan gigi dan mulut. Kesehatan gigi dan mulut didefinisikan sebagai keadaan rongga mulut yag mencakup gigi geligi serta jaringan pendukungnya yang bebas dari penyakit dan dapat berfungsi secara optimal. Kesehatan gigi dan mulut merupakan hal yang sangat penting dan berkaitan dengan kesehatan secara keseluruhan. Selain dengan menyikat gigi rutin 2 kali sehari juga disarankan banyak makan makanan berserat karena dengan makan makanan berserat maka akan terjadi self cleansing dari rongga mulut sehingga debris (sisa makanan) akan mengurangi jumlah sisa makanan yang menempel di permukaan gigi ${ }^{1}$.

Masyarakat di Indonesia hingga saat ini masih kurang dalam mengkonsumsi makanan berserat alami, mengingat serat

*Departemen Bedah Mulut dan Maksilofasial Fakultas Kedokteran Gigi Unissula Semarang,

**Departemen Ilmu Gizi Fakultas Kedokteran Unissula Semarang

Korespondesi: ysitirochmah@yahoo.com 
dalam konsumsi makanan sangat penting. Serat makanan berfungsi untuk mencegah konstipasi (sembelit); mencegah terjadinya penyakit diverticulitis; serta mencegah obesitas yang bisa memicu terjadinya berbagai penyakit seperti diabetes mellitus, atherosclerosis, jantung koroner, dan kanker usus. Serat juga diperlukan untuk menjaga kesehatan gigi dan mulut melalaui mekanisme self cleansing, sehingga penumpukan sisa makanan (debris) disela-sela gigi dapat dikurangi, sehingga berdampak pada penurunan akumulasi plak. ${ }^{1}$

Bahan makanan yang banyak mengandung serat adalah sayuran, buah, biji-bijian, padi-padian, dan kacangkacangan. Sebuah studi yang dilakukan oleh Munte, dkk, tahun 2011, mahasiswa Institut Pertanian Bogor, menemukan bahwa batang pisang muda banyak mengandung serat yang berguna. Batang pisang muda dapat diolah menjadi keripik yang enak dan bergizi. ${ }^{2}$

Pisang sebagai makanan penting menyediakan energi dan kalori bagi tubuh dalam jumlah yang cukup. ${ }^{3}$ Setiap 100 gram pisang segar dan matang memberikan tubuh (100 kalori), yaitu seperti yang diberikan oleh seratus gram daging. Dan seratus gram pisang kering memberikan (250 kalori). Pisang juga mengandung (68\%) air, (25\%) gula, $(2 \%)$ protein, $(1 \%)$, lemak dan minyak, $(1 \%)$ serat Selulosa. Selain itu juga mengandung pati dan asam tanin, vitamin A (300 IU per seratus gram), vitamin B dengan berbagai jenisnya; B1, B2, B 6, dan 12 (100 mg per seratus gram), persentase yang cukup dari vitamin $D$, dan sedikit Vitamin Z, juga mengandung Kalsium (100 mg per seratus gram), Fosfor, Besi, Sodium, Kalium (potassium), Magnesium, dan Seng. ${ }^{4}$

Manfaat pisang untuk kesehatan diantaranya pencegahan Osteomalasia pada anak dan Osteoporosis pada orang dewasa (tua), dan kekurangan kalsium pada wanita hamil dan ibu menyusui, karena mengandung jumlah kalsium yang cukup, yaitu setiap $1 \mathrm{~kg}$ pisang mengandung $1 \mathrm{gr}$ kalsium. Kebutuhan harian kalsium untuk tubuh adalah 1,5 gram, dan kalsium pisang lebih mudah dicerna dibandingkan kalsium susu dan kalsium dari produk susu. Pisang juga mengandung Fosfor dalam jumlah yang cukup,yang bermanfaat dalam perkembangan otak dan kemampuan akal, seperti kecerdasan, berpikir dan menghafal. ${ }^{4,5}$

Pisang juga bermanfaat dalam perlindungan dan pencegahan gigi dari kerusakan. Dan juga bermanfaat untuk radang mulut dan gusi, karena ia mengandung fluoride, yaitu suatu zat penyeteril. Pisang mengandung zat Besi dan vitamin $D$, sehingga berguna dalam pencegahan dan pengobatan anemia dan kekurangan zat Besi, dimana vitamin D mempermudah penyerapan zat besi dalam usus.Vitamin $D$ juga berguna untuk memperkuat gigi pada proses pembentukan gigi (odontogenesis). Pisang mengandung vitamin B 1, B 6, B 12, karena itu ia berguna dalam pengobatan peradangan (infeksi) saraf dan kerusakan saraf, seperti dalam disk (gangguan pada saraf lumbar dan sakral) dan cerebral Bell (gangguan pada saraf wajah). ${ }^{6}$ Vitamin A juga terdapat dalam buah pisang dengan jumlah (300 IU per seratus gram), sedang kebutuhan tubuh akan vitamin A adalah 3500 IU perhari. Vitamin A berguna untuk menjaga kesehatan mata. Dan pisang juga bermanfaat dalam pengobatan diare, jika pisang itu matang namun, jika ia mentah maka ia berguna dalam pengobatan sembelit. ${ }^{7}$ Penelitian baru menguatkan bahwa pisang mengandung hormon-hormon yang berfungsi untuk mengatur aktivitas sistem saraf dan pisang juga bermanfaat dalam pengobatan penyakit psikologis dan depresi, terutama padaanak-anak. ${ }^{8}$ 


\section{METODE PENELITIAN}

Penelitian ini merupakan penelitian observasional analitik. Tempat penelitian adalah Kelurahan Penggaron Lor Semarang mulai April sampai Juni 2014. Instrumen penelitian adalah data primer yang didapat secara langsung dari responden melalui wawancara dan kuisioner yang dibagikan sebelum dan sesudah penyuluhan tentang manfaat tanaman pisang sebagi media menjaga kebersihan gigi dan mulut. Variabel bebas penelitian ini adalah perbedaan pengetahuan ibu-ibu PKK kelurahan Penggaron Lor tentang manfaat tanaman pisang dalam menjaga kesehatan gigi dan mulut sedang variabel terikatnya adalah penyuluhan tentang manfaat tanaman pisang. Populasi penelitian ini adalah semua ibu-ibu PKK Kelurahan Penggaroon Lor Semarang RW 3 dan 4. Sampel penelitian yang digunakan dalam penelitian ini adalah semua ibu-ibu PKK RW 3 dan 4 yang bersedia hadir saat kegiatan dilakukan. Pengambilan sampel
- Item pertanyaan B : Sikap mengenai pembudidayaan tanaman pisang sebagi media untuk menjaga kesehatan gigi dan mulut (ya/tidak)

- Item pertanyaan C : Pemanfaatan tanaman pisang dan pengetahuan umum mengenai tanaman pisang (ya/tidak)

- Item pertanyaan D : Pemanfaatan tanaman pisang dan pengetahuan umum mengenai tanaman pisang (pilihan ganda a,b,c,d atau e)

Karena data tidak normal ( $\mathrm{p}$ value < $0,05)$ maka data diolah menggunakan non parametric test untuk dua sampel berpasangan, yaitu Wilcoxon Sign Ranks test, dan didapatkan nilai $p$ value 0,008 . Artinya terdapat perbedaan bermakna antara nilai rerata pre-test \& post-test.

Artinya penyuluhan telah memberikan dampak yang signifikan terhadap pengetahuan responden terhadap tanaman pisang untuk menjaga kesehatan gigi dan mulut.

Tabel 1. Hasil pre- dan post- test pengetahuan $(n=40)$

\begin{tabular}{lll}
\hline Nilai pre-test (rerata \pm SD) & Nilai post-test (rerata \pm SD) & p value \\
\hline $76,96 \pm 8,05$ & $82,36 \pm 7,00$ & 0,008 \\
\hline
\end{tabular}

secara total sampling dari seluruh ibu kader yang hadir mengikuti kegiatan.

Data yang terkumpul diolah dengan menggunakan program SPSS. Analisis bivariat dengan menggunakan uji Wilcoxon Rank. Tujuan pengujian secara statistik adalah ingin mengetahui apakah ada perbedaan pengetahuan sebelum dan sesudah penyuluhan.

Untuk analisis ini dilakukan empat buah pengujian menurut item pertanyaan, dengan rincian sebagai berikut :

- Item pertanyaan A : Pengetahuan pembudidayaan tanaman pisang sebagai media untuk menjaga kesehatan gigi dan mulut (benar/ salah)

\section{DISKUSI}

Berdasarkan hasil perhitungan SPSS dan kesimpulan yang dapat dibuat adalah Nilai p_value $(0.006)<\alpha(0.05)$ maka Tolak $\mathrm{HO}$ yang berarti terdapat perubahan pengetahuan pembudidayaan tanaman pisang sebagai media untuk menjaga kesehatan gigi dan mulut sebelum dan sesudah penyuluhan. Hal ini menunjukkan bahwa masyarakat sebelum penyuluhan yang dilakukan oleh tim IbM sangat kurang pengetahuan tentang manfaat tanaman pisang sebagai media menjaga kesehatan gigi dan mulut. Dan setelah mendapatkan penyuluhan dari Tim IbM ternyata ibu- 
ibu PKK Kelurahan Penggaron Lor mengalami peningkatan pengetahuan tentang manfaat tanaman pisang bagi kesehatan gigi dan mulut. Hal ini sesuai dengan definisi suatu penyuluhan yaitu suatu proses penyebarluasan informasi (extension) tentang ilmu pengetahuan, teknologi, dan seni yang berasal dari penelitian atau teori kedalam praktek atau kegiatan praktis yang dilakukan secara terus menerus untuk tujuan agar terjadi perubahan perilaku (pengetahuan, keterampilan, dan sikap) pada sasaran penyuluhan." Blum (1986) mengatakan bahwa terdapat 4 faktor yang berpengaruh pada tingkat kesehatan manusia yaitu genetik(hereditas), lingkungan, pelayanan kesehatan, dan perilaku. ${ }^{1}$ Demikian juga dengan perhitungan perilaku juga menunjukkan perbedaan yang signifikan dari sebelum dan sesudah penyuluhan. Hal ini kemungkinan disebabkan oleh tingkat pendidikan ibu-ibu yang minimal SMP (Sekolah Menengah Pertama) atau lulusan dari suatu pondok pesantren sehingga memudahkan untuk merubah pengetahuan dan perilaku ibu-ibu kelurahan Penggaron Lor. Hal ini sesuai dengan teori yang mengatakan bahwa terdapat 3 faktor yang mempengaruhi perubahan perilaku individu maupun kelompok sebagai berikut: (1) Faktor yang mempermudah (Predisposing factor) yang mencakup pengetahuan, sikap, kepercayaan, norma sosial, dan unsur lain yang terdapat dalam diri individu maupun masyarakat.(2) Faktor pendukung (Enabling factor) antara lain umur, status sosial ekonomi, pendidikan, dan sumber daya manusia, (3) Faktor pendorong (Reinforcing factor) yaitu faktor yang memperkuat perubahan perilaku seseorang yang dikarenakan adanya sikap suami, orang tua, tokoh masyarakat atau petugas kesehatan.Serta faktor yang mempengaruhi pengetahuan diantaranya (1) Pengalaman, Pengetahuan dapat diperoleh dari pengalaman baik dari pengalaman pribadi maupun dari pengalaman orang lain. Pengalaman ini merupakan suatu cara untuk memperoleh kebenaran suatu pengetahuan, (2) Ekonomi (pendapatan). Dalam memenuhi kebutuhan pokok (primer) maupun kebutuhan sekunder, keluarga dengan status ekonomi baik akan lebih lebih tercukupi bila dibandingkan keluarga dengan status ekonomi rendah. Hal ini akan mempengaruhi pemenuhan kebutuhan akan informasi pendidikan yang termasuk kedalam kebutuhan sekunder Lingkungan sosial ekonomi, (3) Pendidikan. Tingkat pendidikan seseorang akan berpengaruh dalam pemberian respon terhadap sesuatu yang datangnya dari luar. Orang yang berpendidikan tinggi akan memberikan respon yang lebih rasional terhadap informasi yang datang dan akan berpikir sejauh mana keuntungan yang akan mereka dapatkan, (4) Paparan media massa atau informasi, (5) Akses layanan kesehatan atau fasilitas kesehatan.

Pengukuran pengetahuan dapat dilakukan dengan wawancara atau angket yang menanyakan tentang isi materi yang ingin diukur dari subyek penelitian atau responden (Notoatmodjo,2007). Demikian juga pada penelitian ini dilakukan pengisian kuesioner yang berisi tentang materi penyuluhan untuk mengukur perbedaan pengetahuan sebelum dan sesudah penyuluhan.

\section{KESIMPULAN}

Terdapat perbedaan pengetahuan sebelum dan sesudah penyuluhan, artinya penyuluhan memberikan dampak yg signifikan terhadap pengetahuan responden terhadap manfaat tanaman pisang untuk menajaga kesehatan gigi dan mulut

\section{DAFTAR PUSTAKA}

1. Notoatmodjo, S. 2007.Promosi Kesehatan dan IImu Perilaku. Jakarta : Rineka Cipta

2. Munte, Sarah Intan; Hamdan, Mohamad; Pratomo, Bristoph H.; Putri, Irriwad; Hadi, L. Hanief Remediel (2008) Keripik dari Batang 
Muda Pisang yang Bernilai Serat Tinggi, http:// repository.ipb.ac.id/handle/123456789/33467. Diakses 10 April 2013

3. Saif Al Battar ,(2013) Keajaiban manfaat buah pisang, http://www.arrahmah.com/ news/2013/02/20/keajaiban-manfaat-buahpisang. Diakses 12 April 2013.

4. F.G. Winarno. (2002). Kimia Pangan dan Gizi. Jakarta : Gramedia Pustaka Utama

5. A.Danni.2002."Pemanfaatan Limbah Kulit Pisang Menjadi Pektin”, Tehnik Kimia, Fakultas Tehnik Universitas Diponegoro Semarang

6. Purbowo, M. Lauchil Mahfud, Eka Nia Juniarti(2012), Pemanfaatan limbah kulit pisang sebagai bahan pembuatan pupuk cair, Universitas Trunojoyo Madura.

7. Munadjim,Bsc.1983."Teknologi Pengolahan Pisang”,Gramedia,Jakarta.

8. Rukmana, Rahmat. 1999 Usaha Tani Pisang. Yogyakarta: Kanisius 